\title{
KAJIAN MAKANAN DALAM PERSPEKTIF ANTROPOLOGI
}

\author{
Yevita Nurti ${ }^{1}$
}

Received Article: 08 Mei 2017

Accepted Article: 10 J uni 2017

\begin{abstract}
This article is a literature study explain about the study of food, food habits and nutrition in the Anthropology perspective. The food and nutrition studies reviewed in this article only suggests some examples, which are considered popular and represent the themes in food discussion. The discussion starts from the beginning of anthropologist interest about food in culture until the process it.
\end{abstract}

Keywords: Food Habits, Nutrition, Ritual, Culture Change, Ethnic

\begin{abstract}
Abstrak
Tulisan ini merupakan studi literatur mengenai kajian makanan, kebiasaan makan dan nutrisi dalam perspektif antropologi. Kajian makanan dan gizi yang diulas dalam tulisan ini hanya mengemukakan beberapa contoh, yang dianggap populer dan mewakili tema-tema dalam pembahasan makanan. Pembahasan dimulai sejak awal ketertarikan beberapa antropolog membahas mengenai makanan dalam kebudayaan sampai pada perkembangan kajian kekinian.
\end{abstract}

Kata-Kata Kunci: Kebiasaan Makan, Gizi, Upacara, Perubahan Budaya, Etnis

\section{A. Pendahuluan}

$\mathrm{M}$ akanan tidak hanya penting untuk memenuhi kebutuhan manusia akan makan, namun makanan juga terkait erat dengan kebudayaan, termasuk tekhnologi, organisasi sosial dan juga kepercayaan masyarakat. Makanan tidak akan memiliki makna apa-apa kecuali makanan itu dilihat dalam kebudayaannya atau jaringan interaksi sosialnya.

Kajian mengenai makanan, kebiasaan makan dan gizi, terutama aspek sosial, budaya dan ekonomi makanan pada berbagai kelompok manusia bukanlah hal yang baru dalam sejarah antropologi ${ }^{2}$.

${ }^{1}$ Penulis adalah dosen tetap Jurusan Antropologi FISIP Universitas Andalas

${ }^{2}$ Setidaknya, studi awal antropologi sosial di Inggris telah memfokuskan pada organisasi sosial dan ekonomi pada masyarakat subsistensi non-industri, secara utama pada sumber daya lokal, dan telah mencatat bagaimana mencari, menyiapkan, dan mengkonsumsi makanan yang tersedia dalam aktivitas sehari-hari, dan bagaimana dalam konteks tersebut nilai-nilai makanan emosional Kajian Makanan dalam Perspektif Antropologi
Penelitian yang dilakukan oleh Audrey Richards pada orang Bantu, Afrika Selatan, boleh dikatakan penelitian awal yang cukup populer. Hasil penelitian yang telah dipublikasikan dalam bukunya berjudul Hunger and Work in a Savage Society (1932) tersebut dimulai dengan pernyataan Richards bahwa nutrisi sebagai suatu proses biologis dalam sebuah kebudayaan diatur jauh lebih mendasar daripada urusan seks (bandingkan dengan Bates $(1958)^{3}$ dan Fox, 1994 $)$. Audrey Richard berusaha

dan simbolik sering digunakan dalam ritual untuk menandai status sosial, interval waktu, dan sumber daya lingkungan yang penting secara budaya (Lihat Messer, 1984).

${ }^{3}$ Tulisan Marston Bates (1958) Man, Food, and Sex, yang mengatakan bahwa makanan dan seks - nutrisi dan reproduksi - adalah dua kebutuhan dasar manusia yang berada di bawah kontrol kebudayaan, dan kontrol kebudayaan seringkali memodifikasinya, menghambat dan mengubahnya melalui berbagai cara.

${ }^{4}$ Fox (1994: 39) mengatakan bahwa makanan lebih penting dari seks. Dorongan seksual untuk memastikan kelangsungan genetik dapat

1 | P a g e 
mendeskripsikan bagaimana semua aspek kebudayaan yang ada (termasuk prosesproses ekonomi) mempengaruhi konsumsi makan orang Bantu.

Studi klasik Audrey Richards tentang Bemba (sekarang Zambia) di Rhodesia Utara menyimpulkan bahwa alasan masyarakat Bemba tidak mau menjadi pekerja keras (terutama perhatian terhadap pertambangan British (Inggris) dan minat ekonomi lainnya) bukanlah sebuah pertanyaan yang berkaitan dengan kemalasan namun berkaitan dengan persoalan kurang gizi. Semenjak laki-laki bekerja keras di tambang, perempuanperempuan merasa sangat sulit melakukan tugas pembukaan hutan yang berat yang secara tradisional biasanya dilakukan oleh laki-laki. Selama masa itu bertahun-tahun ketika perempuan lebih membutuhkan makanan bergizi untuk mendukung tenaga dalam membersihkan dan menanam di lahan, supplai makanan amat sedikit. Kemudian, akhirnya mereka terlibat dalam siklus yang terus menerus dalam kondisi kurang produksi dan kurang gizi (Messer, 1984). Orang Bemba sendiri kelihatannya mengakui hubungan antara intake energy yang rendah dan kekurangan energi untuk melakukan pekerjaan, dan secara sadar mereka selalu menghemat energi selama masa kurus dan cuaca dingin. Richards juga mendeskripsikan dimensi sosial dari produksi, persiapan, distribusi, dan konsumsi makanan, mencatat bagaimana semua hubungan kekerabatan dibentuk oleh aturan-aturan sharing yang telah ditetapkan; dan bagaimana kewajiban-kewajiban ini dapat rusak dalam waktu singkat, ketika orang-orang hanya bisa menimbun supplai makanan yang amat sedikit (Messer, 1984).

Di Amerika, studi mengenai kebiasaan makan telah berkembang sejak tahun 1930-an, terutama untuk tujuan antropologi terapan. Kebanyakan studi-studi awal tersebut bertujuan untuk mengan tisipasi penjatahan dan kekurangan maka nan masa perang. Kebanyakan para antropolog waktu itu melakukan studi-studi

terpuaskan beberapa kali selama hidup; sedangkan desakan biologis untuk memenuhi lapar harus dipuaskan setiap hari. Dalam hal makanan selalu ada kebersamaan, dan merupakan urusan kelompok, sedangkan urusan seks individual. yang disponsori pemerintah tentang kebiasaan makanan pada suku tertentu, akibatnya terhadap kondisi gizi, dan jika perlu, bagaimana mengubahnya.

Studi-studi awal tentang makanan lebih banyak menyorot masalah kebiasaan makan sebagai suatu bentuk tingkah laku berpola yang sangat terkait dengan kebudayaan, yang mencakup juga kepercayaan dan pantangan makan yang berkembang dalam sekelompok masyarakat ${ }^{5}$, dan juga berkaitan dengan faktor lingkungan sebagai sumber perolehan bahan pangan yang utama ${ }^{6}$. Pada dasarnya perbedaan-perbedaan makanan pada setiap budaya ini menjadikan konsep makanan berbeda dengan nutrimen. Seperti dikatakan Foster \& Anderson (1986), nutrimen (nutriment) adalah suatu konsep biokimia, suatu zat yang mampu untuk memelihara dan menjaga kesehatan organisme yang menelannya, sedangkan makanan (food) adalah suatu konsep budaya, sesuatu yang dimakan dengan pengesahan budaya. Ini berarti makanan sebagai konsep budaya akan memiliki makna yang lebih luas daripada makanan dalam konsep nutrimen. Makanan dengan pengesahan budaya berarti akan berkaitan dengan kepercayaan, pantangan, aturan, teknologi, dan sebagainya yang tumbuh dan berkembang dalam sekelompok masyarakat, sehingga

${ }^{5}$ Tulisan Bryant et al. (1985: 75) misalnya, yang mengatakan di Cina, daging anak anjing dan daging anak babi yang masih menyusu termasuk ke dalam jenis bahan makanan yang lezat sementara bagi masyarakat yang mayoritas beragama Islam, daging babi dan daging anjing termasuk jenis bahan makanan yang tidak boleh dimakan karena kepercayaan yang diyakini (Bryant at al, 1985:75). Contoh lain, banyak perempuan di India menghindari makan papaya dan telur karena diyakini akan menyebabkan keguguran (Berg \& Muscat, 1985).

6 McElroy dan Patricia K. Townsend mengatakan bahwa pada masyarakat tradisional atau masyarakat pedesaan, perolehan bahan pangan terutama didapatkan dari sumber-sumber yang tersedia di lingkungan. Jika sumber daya alam tidak memenuhi maka perolehan pangan dilakukan melalui pembelian (1985: 46). Lihat juga Jerome, Pelto \& Kandel, (1980: 22).

Kajian Makanan dalam Perspektif Antropologi 
menjadi kebiasaan makan yang menjadi ciri khas sekelompok masyarakat dan yang membedakan dengan kelompok masyarakat lainnya.

Kebiasaan makan sebagai kom pleks kegiatan masak memasak (kulinari) terkait dengan bahan makanan, proses pengolahan, serta tekhnologi yang digunakan. Walaupun kebudayaan menen tukan apa yang bisa dimakan dan tidak, ketersediaan bahan makanan dan makanan dipengaruhi juga oleh komponen ekologis dan fisiologis manusia (Harris dalam Hartog, 1985). Beberapa tumbuhan dan binatang karena sifatnya tidak dapat dicerna oleh manusia, tidak juga dengan menggunakan tekhnologi modern. Oleh sebab itu jenis tumbuhan dan binatang yang tidak bisa dicerna tidak masuk dalam kategori makanan. Contoh lain, susu tidak banyak dikonsumsi pada zone hutan tropis karena kondisi ekologisnya tidak menguntungkan untuk beternak sapi/lembu sebagai penghasil susu. Dan dengan alasan yang sama gandum bukanlah makanan pokok pada masyarakat tropis.

Kajian lain menekankan pada pengaruh atau dampak makanan sebagai klasifikasi budaya tersebut terhadap kesehatan atau gizi masyarakat pendu kungnya. Jerome, Kandel \& Pelto (1980) menyebut istilah ini dengan klasifikasi nonmakanan yang juga berkontribusi terhadap kasus kurang gizi. Misalnya kajian yang dilakukan Gerlach (1964) tentang etiologi spritual atau supernatural yang diappli kasikan terhadap penyakit yang kita kenal sebagai penyebab kurang gizi. Di banyak negara berkembang, kekurangan proteinkalori pada anak-anak kecil diyakini sebagai keseluruhan persoalan non-makanan dan disebabkan oleh pelanggaran tabu atau melanggar supranatural. Sebagai contoh, diantara masyarakat pesisir timur laut Bantul, dimana kwashiorkor termasuk penyakit endemik (selalu mewabah), kurang gizi menurut mereka disebabkan oleh pelanggaran tabu yang melarang orangtua melakukan hubungan seksual selama masa menyusui atau sebelum seorang anak disapih. Ini dipercayai akan menyebabkan terjadinya kehamilan, janin yang belum lahir akan "mencuri" air susu ibu, dan perawatan anak akan terlantar. Sebenarnya tabu ini adaptif membatasi kehamilan dan menguntungkan keduanya, ibu dan pengasuhan anak. Namun, jika kehamilan kedua terjadi dan kemudian dikaitkan dengan pelanggaran tabu (wujudnya adalah kwashiorkor anak), maka mencegah orangtua untuk merawat/mengasuh anak dengan baik (Gerlach, 1964). Contoh lain misalnya dari Buganda. Orang-orang Buganda memahami bahwa kwashiorkor disebabkan oleh kecemburuan janin yang belum lahir terhadap saudaranya yang masih menyusui. Janin tersebut marah dan membuat si anak sakit. Untuk menghindari penyakit ketika kehamilan terjadi, pengasuhan anak seringkali dipisahkan dari ibunya dan diasuh oleh neneknya atau saudara lain yang kadang-kadang tidak menyediakan makanan-makanan yang bernilai gizi. Maksudnya mau melakukan pencegahan, namun tindakan ini justru akan mempercepat kwashiorkor. Ketidakcukupan makanan, dengan trauma psikologis karena dipisahkan dengan ibunya, seringkali memperburuk kondisi (Burgess dan Dean, 1962; Cravioto, 1966; Amann et al. 1972, Jerome, Kandel \& Pelto, 1980). Kwashiorkor yang terjadi akibat perpisahan anak dengan ibunya diistilahkan dengan omusana, di mana diyakini disebabkan oleh malam-malam yang "dingin" yang dilewati seorang anak yang jauh dari ibunya (Burgess \& Dean, 1962:25, Jerome, Kandel \& Pelto, 1980).

Nampaknya banyak kepercayaan masyarakat yang dihubungkan dengan hakekat sumber-sumber makanan secara magic dan semimagic yang dikarak teristikkan rasional dibalik praktek makan semua orang. Beberapa makanan mengacu pada prestise (roti putih dan beras halus); yang lainnya, keamanan (misalnya beras di Asia), dan lainnya sebagai identifikasi kelompok (makanan "etnik") (Jerome, 1970). Larangan-larangan makan dapat dipandang sebagai sebuah ekspresi dari hukum moral Tuhan (seperti kashrut, larangan Islam terhadap babi, larangan sebelum paskah untuk makan daging, dan tabu totem dari beberapa wilayah). Kadang-kadang, kepercayaan terpusat pada hakekat nilai dari makanan yang dikaitkan dengan masamasa kritis dalam life cycle, seperti: kehamilan, menyusui, penyakit, dsbnya. Seringkali, kepercayaan-kepercayaan seper ti ini berpengaruh netral terhadap gizi mereka, misalnya, orang Papago melarang makan garam dan gula pada ibu sampai tali 
pusar bayi lepas (Gonzalez, 1972), atau larangan terhadap binatang menjijikkan atau makanan yang kelihatan menjijikkan untuk melindungi bayi dari pertumbuhan yang jelek (Hughes, 1963). Namun, beberapa tabu makanan juga telah membuang zat-zat gizi yang dibutuhkan, khususnya masamasa kritis. Misalnya larangan terhadap telur dalam makanan wanita usia produktif untuk menghindari sterilitas dan komplikasi kelahiran (HEW, 1973); larangan minum susu bagi ibu menyusui; orang Burma mengurangi daging dan unggas selama masa kehamilan (Mead, 1955), dan lain sebagainya.

Penelitian lainnya menekankan pada fungsi dan peranan makanan dalam masyarakat ${ }^{7}$. Seperti yang ditemukan oleh Kahn, et al (1988) di wilayah Melanesia, Mikronesia dan Polinesia, bahwa makanan mempunyai peranan sosial sebagai sarana adat komunikasi, standar kekayaan, sebuah barometer status sosial, dan sebagai mediator simbolik dalam mendefinisikan dan memanipulasi kekerabatan dan hubungan sosial. Penelitian Davis (1995) di Minangkabau menemukan bahwa makanan bagi orang Minangkabau berfungsi sebagai sesuatu yang bermakna dalam komunikasi antar kelompok, ekspresi yang penting dalam hubungan-hubungan sosial seperti kepercayaan-kepercayaan, kecurigaan, konflik, keselarasan, status, dan simbol hubungan baru dan berkelanjutan.

Pola-pola distribusi makanan dalam keluarga juga memiliki konsekwensi gizi. Masalah makan, identitas atau status individu dalam sebuah keluarga sering menentukan dan menjadi pilihan pertama dalam penyeleksian makanan, dan metode menyiapkan makanan untuk anggota

\footnotetext{
${ }^{7}$ Secara umum Foster dan Anderson mencatat beberapa peranan makanan pada masyarakat yaitu, makanan sebagai ungkapan ikatan sosial, makanan sebagai ungkapan kesetiakawanan kelompok, makanan dan stress dan simbolisme makanan dalam bahasa (1986: 317). Sementara Hartog (1995: 8-10), menyebutkan ada 6 fungsi sosial makanan seperti fungsi gastronomi yang berkaitan dengan selera, struktur atau tekstur, sebagai identitas budaya, berfungsi pada aspek religi dan magic, sebagai makna komunikasi, sebagai ekspresi kekayaan dan status ekonomi, dan berfungsi melatih pengaruh dan kekuasaan.
}

keluarga mempengaruhi siapa yang mendapatkan porsi makanan dengan nilai gizi baik atau buruk.

Pola-pola seleksi makanan, distribusi, dan konsumsi bervariasi dalam tipe-tipe masyarakat yang berbeda. Pada komunitas petani dan pada ekonomiekonomi yang ditandai dengan pertanian subsistensi, anggota-anggota keluarga yang secara ekonomi sangat produktif sering diberikan pilihan pertama memilih lauk yang berkualitas tinggi. Begitu juga dengan peran ibu dalam keluarga, karena ibu merupakan aktor kunci dalam proses produksi dan konsumsi makanan dalam keluarga. Seperti hasil penelitian yang ditunjukkan Marchione (1980:263) di Jamaica bahwa faktor sosialekonomi dan faktor sosial budaya merupakan penyebab terjadinya gizi buruk dikalangan anak-anak. Yang merupakan faktor sosial ekonomi adalah tingkat subsistensi pertanian, sedangkan faktor sosial budaya meliputi kearifan ibu, keharmonisan rumah tangga dan perbedaan ukuran keluarga yang ideal. Marchione menyimpulkan bahwa keluarga yang harmonis, dan usia ibu di atas 30 tahun cenderung memiliki anak-anak yang berat badannya lebih baik daripada anak-anak yang lahir dalam keluarga yang tidak harmonis dan memiliki usia ibu yang relatif muda.

Kebiasaan makan juga berkaitan dengan teknologi, organisasi sosial, dan kepercayaan masyarakat. Penelitian Rappaport pada tahun 1968 pada masyarakat Tsembaga, merupakan satu contoh yang baik bagaimana kebiasaan makan berkaitan dengan teknologi, organisasi sosial, dan kepercayaan masyarakat (Rappaport dalam Bryant et al, 1985: 231-232). Kajian Rappaport (1968) pada masyarakat Tsembaga juga dapat menjadi contoh bagaimana lingkungan (termasuk lingkungan fisik dan sosial) mempengaruhi perkembangan kebudayaan Kajian ini juga menunjukkan bagaimana teknologi, organisasi sosial, dan ideologi bersinergi mempengaruhi pola-pola makan. Masyarakat Tsembaga, yaitu masyarakat yang hidup dari hortikultura dengan membuka hutan dengan tebas bakar di New Guinea. Kebun-kebun mereka menghasilkan talas/keladi, kentang, manioc (tumbuhan yang mengandung zat tepung), sayuran hijau, tebu, dan hasil lainnya untuk 
persediaan makanan. Karena makanan terdiri dari $99 \%$ sayuran, bagaimanapun, tentu kualitas makanan rendah protein. Dengan demikian protein hanya cukup untuk memperoleh keseimbangan nitrogen, namun dalam kondisi stress seseorang akan mudah terganggu keseimbangan nitrogen nya (kekurangan protein), sehingga membutuhkan asupan protein lebih. Masyarakat Tsembaga juga memelihara babi yang dipakai untuk memenuhi beberapa fungsi. Meskipun babi jarang dimakan, namun babi itu menjalankan fungsi teknologi dengan baik, yaitu menjaga kebersihan halaman karena memakan sampah dan kotoran manusia, dan membantu mengorek tanah untuk perkebu nan (seperti mesin pengolahan). Babi akan menimbulkan masalah setelah jumlahnya terlalu banyak, sehingga makanan untuk babi tidak mencukupi lagi. Manusia harus mencari makanan tambahan untuk babi. Di samping itu, jika jumlah babi mulai banyak maka mereka akan merusak kebun, tidak lagi berfungsi sebagaimana mestinya. Untuk mengatasi hal tersebut, masyarakat Tsembaga mengembangkan serentetan upacara ritual (kaiko) yang intinya bertujuan untuk penyembelihan sejumlah besar babi. Dengan penyembelihan babi, asupan protein bagi orang-orang yang membu tuhkan akan terpenuhi dan masalah kelebihan babi akan teratasi.

Kajian Rappaport pada masyarakat Tsembaga tersebut menunjukkan adanya hubungan ritual dengan keseimbangan alam. Nampaknya Rappaport mengga bungkan prinsip-prinsip ekologi biologi dalam studi ekologi kebudayaan, di mana unsur-unsur kebudayaan sama dengan unsur-unsur biologis, tunduk pada seleksi alam, dan akhirnya sekelompok masyarakat dapat dianggap mampu atau tidak mampu menyesuaikan diri.

Beberapa penelitian lainnya menekankan pada makanan dan perubahan makan $^{8}$, walaupun beberapa ahli percaya bahwa kebiasaan makan sangat sulit diubah karena berkaitan dengan fungsi dan peranan sosialnya dan merupakan ekspresi diri $^{9}$. Beberapa faktor yang dapat mengubah

\footnotetext{
${ }^{8}$ Lihat juga Mintz \& Christine M. Du Bois (2002).

9 Mead dalam Sanjur (1982: 286) mencatat adanya perbedaan pada bagaimana para
}

kebiasaan makan dan akhirnya mempengaruhi kondisi gizi tergambar dalam tulisan DeWalt (1993), yang menunjukkan bahwa perubahan pertanian subsistensi kepada komersialisasi telah menyebabkan terjadinya perubahan pada konsumsi makan dan status gizi ${ }^{10}$. Kajian yang dilakukan Eide \& Steady (1980) di daerah rural Afrika tentang perubahan kebiasaan makan yang disebabkan oleh perubahan peranan ibu turut memperkaya kajian perubahan kebiasaan makan ini. Penelitian yang dilakukan Kahn, et al (1988) memperlihatkan bagaimana masyarakat $\mathrm{d}$ wilayah Melanesia dan Polinesia memilih makanan sebagai akibat beragamnya jenis makanan baru yang masuk ke wilayah tersebut.

Agaknya, kajian mengenai "Food Habit" lama terhenti ${ }^{11}$ dan mulai kembali dengan tuntutan persoalan yang lebih luas

imigran mengubah pola makan mereka berkaitan dengan apakah mereka menyukai makanan makanan daerah asal mereka. Para imigran mengubah pakaian dan bahasa mereka pertama karena mereka tidak ingin menyolok. Tetapi makanan adalah urusan pribadi; oleh karena itu, kebiasaan makan diubah terakhir. Namun para imigran di tempat baru, cenderung hanya mengubah makanan pada hari-hari kerjanya tetapi pada hari minggu/libur bersikeras untuk makan makanan asalnya. Lihat juga Foster dan Anderson (1986: 312).

${ }^{10}$ DeWalt menjelaskan pengaruh komersialisasi pertanian pada konsumsi makan dan status gizi yang dilaksanakan lebih kurang dalam rentang 10 tahun. Misalnya penelitian Fleurent \& Fleurent (1980) pada masyarakat Miskito, yang memperlihatkan keseimbangan gizi terjadi sebagai hasil adaptasi manusia dengan lingkungannya, dan sistem hasil panen tradisional. Ketika terjadi perubahan pertanian subsistensi menjadi komersialisasi, seringkali merusak konsumsi makan masyarakat dan status gizi.

${ }^{11}$ Kajian "Food Habit" yang terhenti sekitar 25 tahun setelah The Committe on Food Habits ditinggalkan, formulasi kebijakan untuk "feed the world" telah mendorong kajian antropologi gizi tidak sesederhana untuk kepentingan keilmuan saja, namun meluas pada issu nasional dan global mengenai produksi, distribusi, dan penggunaan makanan (Jerome, Pelto\& Kandel, 1980). 
dan kompleks. Ketika populasi manusia berkembang dan terus meningkat, telah menyebabkan pentingnya peningkatan pada produksi pangan, peningkatan strategi pertanian, peternakan, dan industri pertanian yang memungkinkan untuk meningkatkan sumber-sumber makanan. Ancaman Malthus yang telah menimbulkan pertanyaan serius tentang kemampuan kita untuk menyediakan makanan untuk populasi dunia yang terus meningkat, membutuhkan model-model yang lebih komprehensif untuk memahami sistem makanan manusia, produksi dan distribusi makanan.

Kajian-kajian tentang nutrisi dan makanan mulai mengarah lebih luas ke dalam hal politik dan kebijakan pangan. Misalnya tulisan Susan George dalam bukunya Food for Beginners (1982, 2007), jelas-jelas menolak alasan klise yang menyesatkan tentang penyebab kelaparan di dunia ketiga seperti populasi yang terlalu padat, iklim dan sistem pertanian yang tidak efisien, dan sebagainya. Yang dibahas dalam buku tersebut justru mengetengahkan permainan kejam agribisnis multinasional, metode neo-Malthusian, dan neoKolonialisme, sekaligus membuka topeng pemberi dana yang sok suci sekaligus membongkar akar eksploitasi. Sebagai salah satu contohnya, George (2007) mencatat bencana kelaparan yang terjadi di Irlandia pada tahun 1846-1850 sebagai salah satu bencana kelaparan terparah yang pernah terjadi di Eropa ${ }^{12}$. Ladang kentang yang merupakan makanan pokok gagal panen akibat hama, dan jelas ini merupakan bencana alam, namun kematian sekitar 2 juta orang saat itu jelas bukan bencana alam. Menurut George (2007: 28), selama terjadi bencana kelaparan di Irlandia sebenarnya ada cukup makanan untuk memberi makan dua kali jumlah penduduk yang berjumlah 8 juta orang, namun ekspor besar-besaran bahan makanan, mulai dari gandum, oat, barley (jenis gandum yang dipakai untuk membuat bir), ternak, telur, dsbnya, belangsung terus. Karena bahanbahan makanan tersebut dianggap sebagai bahan makanan perdagangan (untuk

\footnotetext{
12 Seorang sejarawan Eropa mencatat telah terjadi 89 kali bencana kelaparan besar-besaran antara abad 10 dan abad 18 - artinya rata-rata bencana kelaparan melanda Eropa setiap sepuluh tahun sekali (George, $2007: 26$ ).
}

6 | P a g e komersial) dan memang ditanam hanya sebagai komoditas ekspor dan untuk mendatangkan keuntungan. Para petani Irlandia tidak pernah memakannya karena mereka hanya menanamnya untuk tuan tanah, dan disebabkan juga karena mereka tidak mampu membayar sewa tanah. Harga sewa tanah yang amat mahal membuat para petani tidak bisa menyewa tanah dan semakin terjerat dalam kemiskinan. Kemiskinan dan ancaman kelaparan membuat orang-orang Irlandia saat itu melakukan emigrasi ke Amerika atau ke Inggris. Menurut George (2007), kelaparan dan kurang gizi yang terjadi saat ini di Negara-negara Dunia Ketiga mirip dengan yang terjadi di Irlandia itu. Para petani terpaksa mengekspor makanan pada masa kelaparan demi keuntungan tuan tanah, terbeban hutang yang melilit dan sewa tanah yang tinggi, serta ancaman diusir oleh tuan tanah. Sementara itu kebanyakan orang tidak memiliki tanah dan tidak cukup tersedia lapangan pekerjaan. Jadi persoalannya bukan hanya kelaparan semata atau kurang pangan semata, namun juga penindasan. Ini yang kemudian disebutnya dengan ancaman neoKolonialisme. Tulisan George ini jelas menguak "sisi lain" sebagai penyebab terjadinya kelaparan dan kurang gizi, namun permasalahan yang dilihat secara global tersebut belum tentu bisa dijadikan acuan untuk berbagai kelompok masyarakat yang hidup di wilayah tertentu, dengan lingkungan dan permasalahan/kebijakan pangan yang berbeda-beda.

\section{B. Kajian Makanan Sebagai Simbol \\ $\mathrm{M}$ emasak dan memakan diilhami dengan makna-makna khusus. Memasak dan makan berhubungan} dengan banyak identitas individual, dan idiom-idiom serta ideologi-ideologi tersebut akan mempengaruhi pilihan makan. Simbolsimbol diciptakan dan diciptakan kembali kapan saja, dengan sebuah pola makna dan signifikansi. Banyak objek, tindakan, peristiwa, ungkapan/upacara, konsep atau citra yang mengacu sebagai material mentah untuk menciptakan simbol, pada banyak tempat, dan waktu. Misalnya, karakteristik fisik dari bahan makanan dapat menjadi lambang. Sebagai contoh, tahun 1972-1973 pemerintah Amerika dalam Program Perdamaian mengirim jagung

Kajian Makanan dalam Perspektif Antropologi 
kuning ke Boeswana untuk didistribusikan ke sekolah-sekolah sebagai bantuan selama masa kekeringan. Memalukan dan dihina dengan ber ton-ton jagung kuning yang diberikan pada mereka, pelajar-pelajar di sekolah di Serowe, membakar mobil kepala sekolah dan menghancurkan tumpukan jagung kuning tersebut. Ini disebabkan karena mereka menganggap hanya jagung putih yang dikonsumsi manusia, sedangkan jagung kuning adalah makanan hewan (Jones, 2007). Orang-orang mendefinisikan peristiwa melalui makanan, sepotong hot dog di pantai, coklat panas di rink ice skating, dan popcorn di bioskop. Makanan juga memperkenalkan tempat, dari wilayah kota ke kota kecil atau lingkungan, misalnya bubur Peninsula Upper Michigan, cabe Cincinnati Ohio. Makanan juga "membuat" tempat, seperti orang-orang Jepang Amerika di camp-camp selama PD II yang membangun batas teritorial mereka dengan menggunakan kantin/ruang makan, kebun, wajan panas, tofu - membuat fasilitas dan memori-memori makanan sebagai "ruang" untuk memperluas aktivitas politik dan menciptakan identitas kolektif. Seringkali makanan disimpan dengan emosi. "Saya merasa baik jika saya makan banyak jenis makanan pada kesempatan khusus", pernyataan seseorang. Makanan juga sebagai teman, penghibur, dan hobby. Makanan digunakan orang juga sebagai suatu hadiah. Makanan juga sebagai suatu ekspresi simpati dan dukungan ketika seorang teman sakit atau ada anggota keluarga yang meninggal. Dalam interaksi sosial yang melibatkan makanan, individu sering membuat keputusan tentang dengan siapa dia ingin makan, dengan siapa dia tidak ingin makan. Beberapa studi memperlihatkan orang-orang yang makan dengan teman mengkonsumsi lebih banyak makanan dibanding makan dengan orang asing (Jones, 2007).

Makanan sebagai simbol-simbol tertentu akan memiliki makna-makna tertentu dalam banyak aktivitas sosial. Misalnya dalam makanan yang digunakan dalam perayaan adat, upacara adat atau upacara perkawinan. Makanan tidak hanya sesuatu untuk dimakan, atau sesuatu untuk disuguhkan kepada tamu atau anggota kerabat yang sedang mengikuti perayaan, tetapi makanan, jenis makanan, serta tatacara penyajiannya menjadi simbol-

Kajian Makanan dalam Perspektif Antropologi simbol budaya tertentu. Misalnya kajian Mohamed, dkk (2010), tentang makanan hantaran dalam perkawinan Melayu Kelantan. Kajiannya menunjukkan bahwa makanan-makanan hantaran dalam upacara perkawinan pada masyarakat Melayu Kelantan merupakan simbol-simbol yang sarat dengan makna yang diyakini oleh masyarakat sampai sekarang. Pesan-pesan yang disampaikan melalui makanan dan perilaku makanan ini pada akhirnya memperluas kajian makanan sebagai simbol.

\section{Makanan Sebagai Pembentuk Identitas Etnis \\ akanan juga sebagai pembentuk identitas etnis, yang dapat dikenali} memiliki karakterisitik rasa yang khusus. Misalnya, masakan Minahasa ditandai dengan penggunaan cabai (rica) dalam jumlah yang banyak dalam mengolah daging, begitu kuatnya rasa cabai sampaisampai menghilangkan rasa daging itu sendiri ${ }^{13}$. Begitu juga masakan Minangkabau, cabai, santan, dan bumbu rempah-rempah menjadikan makanannya khas sebagai makanan Minangkabau ${ }^{14}$. Makanan juga sebagai pembentuk identitas individual yang berkaitan dengan klas dan gender. Goody (1982) menyebutkan bahwa sebetulnya hirarki klass, kasta, ras dan gender terbentuk melalui differensiasi kontrol terhadap akses terhadap makanan ${ }^{15}$. Pola-pola konsumsi yang berbeda adalah satu dari banyak cara yang membedakan diri mereka sendiri dengan orang miskin dan membedakan laki-laki dengan perempuan ${ }^{16}$. Makanan juga mempunyai peranan sosial sebagai sarana adat komunikasi, standar kekayaan, sebuah barometer status sosial, dan sebagai mediator simbolik dalam mendefinisikan dan memanipulasi kekerabatan dan hubungan sosial ${ }^{17}$.

\footnotetext{
${ }^{13}$ Weichart, 2004: 67

${ }^{14}$ Davis, 2007

${ }^{15}$ Goody, 1982 dalam Counihan, 1998.

16 Bennett 1943; Fitchen 1988; Mintz 1985; Weismantel 1988, dalam Counihan, 1998

${ }^{17}$ Kahn, et al (1988). Penelitian Davis (1995) di Minangkabau menemukan bahwa makanan bagi orang Minangkabau berfungsi sebagai sesuatu yang bermakna dalam komunikasi antar kelompok, ekspresi yang penting dalam
} 


\section{Makanan dan Perubahan}

D alam beberapa tahun terakhir, kajian makanan menyangkut perubahanperubahan yang terjadi akibat masuknya berbagai jenis makanan dari luar, sebagai akibat perubahan yang disebut globalisasi. Di seluruh dunia, barang-barang seperti makanan dan pakaian digunakan dengan cara yang berbeda oleh kelompokkelompok sosial dan klass sosial yang berbeda (misalnya Bourdieu, 1984). Bahkan para ahli antropologi ekonomi telah menjadi semakin tertarik pada hubungan antara konsumsi dan pengalaman sosial, terutama dalam kaitannya dengan konsumsi komoditas global (misalnya tulisan Friedman 1994; Miller 1995). Dengan menekankan pada komponen konsumsi, para ahli telah membawa perhatian pada berbagai variasi motivasi untuk mengkonsumsi barangbarang tertentu dan kontestasi makna yang muncul akibat perilaku mengkonsumsi ini. Dan, karena adanya makna-makna budaya lokal yang terus menerus melekat pada konsumsi barang-barang dari luar, mereka berpendapat bahwa konsumsi tidak menandakan persaingan dengan budaya Barat atau dengan kata lain keaslian budaya lokal tidak akan menghilang (Miller 1995; Wilk 1994).

Menurut Friedman (1994), pada dasarnya penerimaan atau peniruan unsur budaya luar ini sangat tergantung bagaimana sebuah komunitas memahami dan menafsir ulang (redefinition) pengetahuan baru tersebut. Itulah sebabnya walaupun budaya global akan selalu memiliki kemiripan di berbagai wilayah, namun sebenarnya tetap mendapatkan ciri lokal (local identity) di setiap wilayah yang ditempatinya. Ini berarti juga bahwa satu unsur budaya yang sama bisa mendapatkan perbedaan fungsi dan makna di setiap komunitas yang ditempatinya. Misalnya saja kue pengantin, yang konon berasal dari tradisi Romawi Kuno sebagai lambang kesuburan juga digunakan dalam perkawinan Minangkabau sebagai pembawaan dari pihak pengantin

hubungan-hubungan sosial seperti kepercayaan-kepercayaan, kecurigaan, konflik, keselarasan, status, dan simbol hubungan baru dan berkelanjutan.

$8 \mid \mathbf{P}$ a g e perempuan kepada pihak pengantin lakilaki.

Makanan dan perubahan budaya makan sebagai akibat masuknya makananmakanan asing tidak hanya mempengaruhi praktik makan sehari-hari, namun juga pada acara-acara tradisional seperti perkawinan. Seperti dikatakan Miele (1999), makananmakanan dimodifikasi sesuai dengan trend baru dalam konsumsi, yang oleh Miele digambarkan sebagai munculnya arena baru makanan pasca modern dan budaya konsumsi baru dikalangan konsumen. Pilihan-pilihan terhadap jenis makanan tertentu atau pilihan tatacara terhadap konsumsi tertentu pada akhirnya memunculkan gaya hidup baru, yang dianggap membawa satu kenyamanan dalam mengkonsumsinya. Sheely (2008), mengidentifikasi beberapa hal yang membuat orang menginginkan kenyamanan dalam memilih makanan yang pada akhirnya berkontribusi terhadap perubahan tersebut, seperti misalnya perubahan struktur rumah tangga, tingginya partisipasi perempuan dalam angkatan kerja dan jam kerja yang lebih panjang, kemakmuran konsumen, keinginan untuk pengalaman baru, keterampilan memasak menurun, serta menguatnya nilai uang. Kenyamanan dalam konsumsi makanan ini pada gilirannya mempengaruhi orang untuk beralih dari makanan tradisional, yang dimasak sendiri, yang cenderung dianggap merepotkan, menghabiskan banyak waktu dan tenaga, dan lain sebagainya. Makanan asing telah bekerja untuk membawa perubahan dan kelanjutan preferensi makanan melalui mobilisasi-mobilisasi yang berbeda dari identitas kelas.

James (1997) mengkaji isu kelas dan status sosial di Inggris sebagai bentuk perbedaan yang disimbolkan dengan makanan. Dia menjelaskan walaupun di Inggris telah terjadi proses 'creolisation' (percampuran) makanan, terutama dengan meningkatnya pertumbuhan restoran pizza dan kebab, makanan pesan antar (take away) dari restoran Cina dan India, serta pertumbuhan berbagai makanan yang tersedia di supermarket yg menggambarkan tradisi-tradisi kuliner lainnya, orang-orang Inggris tetap kembali kepada gastronomi regional dan lokal. Kecendrungan kembali kepada makanan lokal ini ditinggalkan oleh keluarga kelas menengah atas pada abad

Kajian Makanan dalam Perspektif Antropologi 
18 dan 19 ketika mereka kembali ke makanan Perancis, namun perlu dicatat itu hanya untuk mempertahankan sebuah status tinggi, dan makanan dengan harga yang mahal. Mannell (1985) mencatat bahwa, tradisi makanan di Inggris berhubungan dengan makanan dan identitas kelas sosial secara kompleks ditandai dan dilihat mulai abad 19. Identitas kelas Inggris secara ironis dibangun melalui mediasi makanan Perancis (makanan asing). Sebaliknya, berbeda dengan masakan yang sangat rumit yang telah dikembangkan dalam masyarakat Perancis selama abad 17 dan 18, para bangsawan Inggris telah terus hidup dari tanah mereka, memakan secara sederhana daging dan puding. Selama Abad 19, ada pengembangan peningkatan ketergantungan pada kuliner Perancis seperti kaum elit meninggalkan makanan tradisional dan masakan negaranya dan mengadopsi makanan Perancis dan masakan Perancis. Ini adalah bentuk hegemoni Perancis yang diperluas juga di Eropa dan Amerika Utara, dan mempengaruhi cara dimana makanan, tatacara makan menjadi terstruktur (Caplan, 1997).

Dalam bukunya Distinction (1986, 1979 via Caplan, 1997), Bourdieu mengatakan bahwa kelas-kelas yang lebih tinggi menggunakan makanan, sama seperti mereka menggunakan selera dalam musik, seni atau pakaian, untuk membedakan mereka dengan kelas yang lebih rendah. Kemudian, dalam rangka membedakan status ini, mereka (kelas yang lebih tinggi) mengubah selera, dan terus mengubahnya. Bourdieu lebih melihat selera sebagai putusan estetis, yaitu produk dari adanya perbedaan kelas ketimbang pengakuan atas standar kualitas. Selera adalah sesuatu yang dikonstruksi secara sosial dalam ruang sejarah yang konkrit. Apa yang dibaca, dilihat, dimakan, dan sebagainya bukan merujuk pada rasionalitas selera murni, atau tanpa kepentingan, namun selama itu berlangsung di dalam ranah sosial, putusan estetis, sudah pasti mengusung berbagai kepentingan, walaupun kepentingan itu sejauh pada kepentingan simbolik (Blunden, 2004). Menurut Bourdieu, hal-hal simbolik dalam ranah perjuangan kelas dan kekuasaan sangatlah strategis, karena memiliki legitimasi untuk melakukan dominasi.

\section{E. Kesimpulan \\ asalah kebiasaan makan sebagai suatu bentuk tingkah laku berpola yang sangat terkait dengan kebudayaan, yang mencakup juga kepercayaan dan pantangan makan yang berkembang dalam sekelompok} masyarakat. Makanan dengan pengesahan budaya berarti akan berkaitan dengan kepercayaan, pantangan, aturan, teknologi, dan sebagainya yang tumbuh dan berkembang dalam sekelompok masyarakat, sehingga menjadi kebiasaan makan yang menjadi ciri khas sekelompok masyarakat dan yang membedakan dengan kelompok masyarakat lainnya. Makanan sebagai simbol-simbol tertentu akan memiliki makna-makna tertentu dalam banyak aktivitas sosial. Misalnya dalam makanan yang digunakan dalam perayaan adat, upacara adat atau upacara perkawinan. akanan juga sebagai pembentuk identitas etnis, yang dapat dikenali dari jenis masakannya yang memiliki karakterisitik rasa yang khusus. Makanan dan perubahan budaya makan sebagai akibat masuknya makananmakanan asing tidak hanya mempengaruhi praktik makan sehari-hari, namun juga pada acara-acara tradisional seperti perkawinan

\section{Daftar Pustaka:}

Bates, Marston (1984). "Manusia, Makan dan Seks" dalam Manusia, Kebudayaan dan Lingkungannya (Parsudi Suparlan, ed). Jakarta: Penerbit Rajawali.

Berg, Alan \& Robert J.Muscat (1985). Faktor Gizi. (terjemahan oleh Achmad Djaeni Sediaoetama). Jakarta: Penerbit Bhratara Karya Aksara.

Bryant, et al. (1985). An Introduction to Food and Society : The Cultural Feast. West Publishing Co, USA.

Caplan, Pat. (1997). "Approach to the Study of Food, Health and identity". Dalam Food, Health and Identity (Caplan, Ed), hal 1-32. London: Routledge. 
Cassidy, C.M. (1980) "Nutrition and Health in Agriculturalists and Hunter Gatherers : A Case Study of two Prehistoric Populations," Nutritional Anthropology (Jerome, Kandel \& Pelto, ed). Redgrave Publishing Company, USA.

Cassel, John (1977) "Social and Cultural Implications of Food and Food Habits," Cultural, Disease and Healing: Studies on Medical Anthropology (David Landy, ed). New York: Macmillan.

Davis, Carol (1995) "Hierarchy or Complementary? Gendered Expression of Minangkabau Adat" dalam Indonesia Circle No. 67, hal 273-292.

Den Hartog, et al. (1995). Manual for Social surveys on Food Habits and Consumption in Developing Countries. Germany: Margraf Verlag.

DeWalt (1993). Agriculture Comercialization and Nutrition. Social Science Medicine, Vol. 36.

Fitzgerald, ed (1977). Nutrition and Anthropology in Action. Van Gorcum \& Comp. B.V. Assen, The Netherlands.

Foster, George M \& Barbara G Anderson (1986). Antropologi Kesehatan. Penerjemah Priyanti S. Pakan dan Meutia F. Swasono). Jakarta: UI Press.

George, Susan (2007). Pangan : Dari Penindasan Sampai Ke Ketahanan Pangan. Yogyakarta: INSIST Press.

Gerlach, LP. (1964). "Socio-Cultural Factors Affecting the Diet of the Northeast Coastal Bantu" dalam Journal of the American Dietetic Association 45: 420-424.

James, Allison (1997). "How British is British"? Dalam Food, Health and Identity. (Caplan ed). London: Routlegde. Hal 75-88.

Jerome, Pelto, Kandel (eds). 1980. "Introduction", dalam NutritionalAnthropology (Jerome, Pelto \& Kandel, eds). United States of America : Redgrave Publishing Company.

Joes, Michael Owen (2007). "Food Choice, Symbolism and Identity". The Board of Trustees of the University of Illinois.

Kahn, Miriam (1988). "The Fresh and The Canned: Food Choices in Pacific", dalam Food and Foodways, 1988. Vol 3, pp 1-18. Harwood Academic Publishers.

Marchione (1980) "Factors Associated with Malnutrition in the Children Of Western Jamaica" Nutritional Anthropology (Jerome, Kandel \& Pelto, ed). Redgrave Publishing Company, USA.

McElroy, Ann. \& patricia K.Townsend. (1994). Medical Anthropology in Ecology Perspective. Duxbury Press: North Scituate, Massachusetts.

Messer, E (1984). "Anthropology Perspectives on Diet" dalam Annual Review of Anthropology Vol. 13, pg. 205-249.

Miele, M. (1999). "Short circuits: new trends in the consumption of food and the changing status of meat" dalam International Planning Studies, Vol. 4(3), hal. 373-387.

Rappaport, Roy. 1968. Pigs For The Ancerstors: Ritual in Ecology of a New Guinea People. USA: Yale University.

Messer, E (1984). "Anthropology Perspectives on Diet" dalam Annual Review of Anthropology Vol. 13, pg. 205-249.

Sheely, M. (2008). "Global adoption of convenience food" dalam American Journal Agro Economic, Vol. 90(5), hal. 1356-1365.

Sidney W. Mintz \& Christine M. Du Bois. 2002. The Anthropology of Food and Eating

Sanjur, Diva (1982). Social and Cultural Perpectives in Nutrition. Prentice Hall, INC, Englewood Cliffs.

Weichart G. (2004). "Identitas Minahasa - Sebuah Praktik Kuliner" dalam Antropologi Indonesia, Vol. 28(74), hal. 59-80.

Wilk, Richard (1994). "Consumer Goods as Dialogue About Development: Colonial Time and Television Time in Belize" dalam Consumption and Identity. (Jonathan Friedman, ed), hal. 97-109. Chur, Switzerland: Harwood Academic Publishers. 